\title{
Conformational Fingerprinting Using Monoclonal Antibodies (on the Example of Angiotensin I-Converting Enzyme-ACE) ${ }^{1}$
}

\author{
S. M. Danilov ${ }^{a, b, c}$ \\ ${ }^{a}$ University of Illinois at Chicago, Chicago, USA \\ ${ }^{b}$ Arizona University, Tucson, USA \\ ${ }^{c}$ Medical Scientific and Educational Center of Moscow State University, Moscow, 119991 Russia \\ e-mail:danilov@uic.edu
}

Received May 7, 2017; in final form, June 2, 2017

\begin{abstract}
During the past 30 years my laboratory has generated 40+ monoclonal antibodies (mAbs) directed to structural and conformational epitopes on human ACE as well as ACE from rats, mice and other species. These mAbs were successfully used for detection and quantification of ACE by ELISA, Western blotting, flow cytometry and immunohistochemistry. In all these applications mainly single mAbs were used. We hypothesized that we can obtain a completely new kind of information about ACE structure and function if we use the whole set of $\mathrm{mAbs}$ directed to different epitopes on the ACE molecule. When we finished epitope mapping of all mAbs to ACE (and especially, those recognizing conformational epitopes), we realized that we had obtained a new tool to study ACE. First, we demonstrated that binding of some mAbs is very sensitive to local conformational changes on the ACE surface-due to local denaturation, inactivation, ACE inhibitor or mAbs binding or due to diseases. Second, we were able to detect, localize and characterize several human ACE mutations. And, finally, we established a new concept-conformational fingerprinting of ACE using mAbs that in turn allowed us to obtain evidence for tissue specificity of ACE, which has promising scientific and diagnostic perspectives. The initial goal for the generation of mAbs to ACE 30 years ago was obtaining mAbs to organ-specific endothelial cells, which could be used for organ-specific drug delivery. Our systematic work on characterization of mAbs to numerous epitopes on ACE during these years has lead not only to the generation of the most effective mAbs for specific drug/gene delivery into the lung capillaries, but also to the establishment of the concept of conformational fingerprinting of ACE, which in turn gives a theoretical base for the generation of mAbs, specific for ACE from different organs. We believe that this concept could be applicable for any glycoprotein against which there is a set of mAbs to different epitopes.
\end{abstract}

Keywords: angiotensin I-converting enzyme, monoclonal antibodies, conformation, tissue specificity, drug/gene lung targeting

DOI: $10.1134 / \mathrm{S} 0026893317060048$

\section{INTRODUCTION}

In 1975, George Kohler and Cesar Milstein published the article in Nature, that later became famous, about the generation of the immortal cell lines (hybridomas) that produce monoclonal antibodies (mAbs) of the predefined specificity [1]. This method, for which they were awarded the Nobel Prize in Physiology and Medicine in 1984, quickly changed the diagnostics, almost completely replacing polyclonal antibodies in the quantitative determination of all proteins and thousands of other substances using ELISA, Western blotting, immunohistochemistry as well quantification of cell subpopulations using flow cytometry.

In recent years, the $\mathrm{mAb}$ has begun to dramatically change the therapy (and, first of all, cancer therapy). Currently, more than $80 \mathrm{mAbs}$ are used in the therapy

\footnotetext{
${ }^{1}$ The article was translated by the author.
}

of many cancers, autoimmune and other diseases. The irony is that the profits of pharmaceutical companies from the sale of mAbs are now estimated at dozens of billions of dollars, whereas in 1975 the Office of the Technology Transfer of the famous Laboratory of Molecular Biology (Cambridge, UK) refused to promote the patent application, considering it "commercially unpromising" [2].

In 1983, at the Institute of Experimental Cardiology (belonging to National Center of Cardiology, Moscow USSR) where I was working at the time, the director of the Institute, Vladimir Smirnov, organized new group for the generation of mAbs against various proteins, which were of interest to the various laboratories of our Institute and our collaborators. For a relatively short period of time, the staff of this group (led by Ilya Trakht), along with interested users, generated dozens of mAbs to various proteins. 
My group, which was cultivated and studied endothelial cells (cells lining blood vessels), was interested in the possibility of mAbs generation, capable of recognizing the endothelium of capillaries of different organs, which differed both functionally and morphologically [3]. Such antibodies, whether they were obtained, could be used for targeted delivery of drugs or genes to different organs (one of the approaches studied intensively in our Institute).

To obtain antibodies recognizing the organ-specific endothelium, first we (with Elena Allikmets (Sadovnikova) in 1984 developed an effective method of culturing human endothelial cells (using a set of human growth factors [4], and then a pure cultures of endothelial cells of the capillaries of the lungs, liver and kidneys were obtained.

However, this took more than a month for the cloning and verification of these cells, and as a result we obtained one $35 \mathrm{~mm}$ Petri dish of each type of cells, which, of course, could not be sufficient for immunization of mice and subsequent screening of the hybridomas.

An alternative approach to the production of organ-specific antibodies could be the generation of $\mathrm{mAbs}$ to membrane proteins on the surface of endothelial cells, the structure of which differed in different human organs. Ivan Sakharov, who at that time worked at our Institute, proposed that angiotensinconverting enzyme (ACE) could be such protein, while honestly speaking, scientific ground for this hypothesis was practically absent.

\section{SHORT CHARACTERISTICS OF ACE}

ACE is Zn-dependent $\mathrm{C}$ terminal dipeptidase (MW about $170 \mathrm{kDa}$ ), which metabolize different biologically active peptides (Angiotensin I, bradykinin, Ac-SDKP) and play a key role in the blood pressure regulation and vascular remodeling. Besides, this enzyme participates in the metabolism of neuropeptides, immune and reproductive function, cell signaling $[5,6]$.

ACE is glycoprotein and integral membrane protein of type I and accepted as Cluster Differentiating antigen - CD143 [7]. Main physiological functions of ACE performed by membrane-bound enzyme [8] on the surface of endothelial, epithelial and neuroepithelial cells ([9] and references herein) and also immune cells (macrophages and dendritic cells $[10,11]$. Membrane-bound secretase (which still is not identified) cleaved ACE from the surface in the stalk region, above transmembrane anchor [12]. Soluble ACE was found in the blood, seminal and other biological fluids.

The concentration of ACE in the biological fluids considered as an important clinical parameter. In a healthy population ACE levels is quite stable with a time [13], while significantly increased at sarcoidosis [14] or Gaucher disease [15, 16]. Besides, ACE gene polymorphism lead to 3-4 fold differences in blood ACE levels in population [17, 18]. And, finally, mutations in ACE gene lead to dramatic decreased in ACE surface expression [19], or significant increase in ACE shedding from the cell surface $[20,21]$ or secretion from the cells [22, 23], which increased ACE levels in the blood 5-15 fold (respectively).

There are two form of ACE in humans-somatic (tissue) ACE and testicular ACE (on spermatozoa). Somatic form of ACE consists of two homologous domains ( $\mathrm{N}$ and $\mathrm{C}$ ) in one polypeptide chain and each domain has active center [24]. Testicular ACE has one domain (one active center) and practically completely correspond to $\mathrm{C}$ domain of somatic ACE. Crystal structure of somatic ACE is still not obtained, but reliable models were proposed based on crystal structures of the single $\mathrm{N}$ and $\mathrm{C}$ domains and electron microscopy picture of somatic enzyme.

Increased expression of ACE is one of the reasons for diabetic nephropathy, hypertension and some other cardiovascular complications, that is why ACE inhibitors, introduced in the clinical practice more than 30 years ago became drugs of 1 st choice at several cardiovascular diseases [26].

The story described below is an illustration of the fact that despite of an absence of strong scientific background of the organ-specificity of ACE at time when we started the project, systematic and intensive work on generation and characterization of numerous $\mathrm{mAbs}$ to different epitopes of ACE during these years lead not only to the generation of the most effective mAbs for targeted gene and drug delivery to the lung endothelium, but also to the establishment of the concept of conformational fingerprinting of ACE, which in turn, gave theoretical base for the generation of $\mathrm{mAbs}$ specific for ACEs from different human organs.

\section{GENERATION OF MONOCLONAL ANTIBODIES TO HUMAN ACE}

First immunization of mice was performed by the mixture of ACEs, isolated by I. Sakharov's team from different human organs [27-29]. We planned that positive clones of hybridomas, selected on the mixture of ACE from different organs, will be tested then on each ACE separately. However, as a result of the mistake (detergent Tween-20 $(0.05 \%)$ was not added into washing buffer) we selected a lot of false-positive populations of the hybridomas, that were not confirmed later in more specific test-precipitation of ACE on the bottom of the wells in microtiter plate by $\mathrm{mAbs}$ with determination of ACE activity (immunocapture enzyme immunoassay) [30]. Therefore, we carried out the following immunization with an ACE from the lungs (which was available in sufficient quantity).

When in 1983 the work on mAbs generation to various proteins began in our Institute, it was considered unconditional luck simply to obtain at least one mAb 
(i.e., a unified reagent produced in unlimited amounts), specifically binding to the protein of interest with high affinity.

Therefore, the selection of positive hybridomas was built on a single template (as until recently and throughout the world): several hundred hybridomas were screened and one population was selected with the strongest signal, which was cloned and propagated to obtain a stable hybridoma producing antibodies of the highest affinity.

Intuitively, I assumed that if several antibodies could be obtained to different epitopes of the protein of interest (in our case, ACE), then such antibodies can serve as structural and functional "probes" for those parts of the antigen where their epitopes are located. (Later I found a series of articles by S.J. Tzartos, devoted to the study of the acetylcholine receptor using the mAbs panel to different epitopes [31], which confirmed my thoughts).

Therefore, during primary screening of hybridomas (generated and cultivated by Elena Allikmets (Sadovnikova) and Ilya Trakht) using ELISA on pure lung ACE we selected ALL positive populations (127), which I tested further on antigen-binding properties in immunocapture test [32], that eliminated possible false-positive (in ELISA) hybridomas with heterofilic antibodies) [33].

Using such double-tests we generated 14 populations of the hybridomas, that produced 8 non-identical mAbs against human lung ACE, that were cloned and carefully characterized [30]. All these $8 \mathrm{mAbs}$ from 1st successful hybridization recognized epitopes on the $\mathrm{N}$ domain of ACE. Two of them were stained denatured ACE in Western blotting (i.e. recognized sequential, linear, continuous epitopes), while other six mAbs bound only native, catalytically active ACE in solution or immobilized on the plastic (i.e. recognized conformational, discontinuous epitopes).

I should also mention that all mAbs from the other series of $\mathrm{mAbs}$ to ACE, that were obtained by H. Towbin and F. Alhenc-Gelas, which were analysed in the same paper [30] recognized only linear (continuous) epitopes of ACE. Positive population of hybridomas in this series were selected using purified human kidney ACE, that was labeled by I-125. Likely, during radiolabeling procedure, pure ACE was significantly denatured, therefore hybridomas were selected that produced mAbs recognizing linear epitopes. Later we demonstrated that even simple adsorption of catalytically active ACE to the plastic for ELISA results in partial denaturation [34]. Therefore, during generation of mAbs to conformational epitopes of ACE (and likely, other proteins) catalytically active ACE (or other proteins) preferably should be used in solution, because any manipulation with ACE (including simple sorption on plastic) lead to partial denaturation.

Naturally, we also wanted to get a panel of mAbs recognizing epitopes on the surface of the $\mathrm{C}$-domain of the ACE, so together with Irina Balyasnikova we received two sets of $\mathrm{mAbs}$ against linear (denatured) and native (conformational, discontinuous) epitopes on the surface of the human C-domain and characterized it in detail $[35,36]$. To exclude the possible masking effect of the $\mathrm{N}$-domain on the immune response to epitopes located on the C-domain of the ACE (due to the masking of part of the $\mathrm{C}$ domain of the $\mathrm{N}$-domain globule [37]), the mice were immunized with purified recombinant testicular ACE (expressed in CHO cells), which contains only the C-domain. As a result, we obtained $8 \mathrm{mAbs}$ to conformational epitopes and $8 \mathrm{mAbs}$ to denatured epitopes on the $\mathrm{C}$ domain of human ACE. A few more years have been spent on complete epitope mapping of all these mAbs [34-36, 38-42], conducted jointly with the groups of Olga Kost (Moscow University) and Edward Sturrock (University of Cape Town, South Africa).

When we finished epitope mapping of all mAbs to human ACE we realized that we obtained a very powerful tool to study ACE.

First of all, we demonstrated that the binding of some mAbs was extremely sensitive to local changes in ACE conformation-due to local denaturation or inactivation, binding of ACE inhibitors or antibodies to ACE, or due to several diseases [34, 39, 40, 43-45].

Secondly, we were able to detect and localize several ACE mutations [21-23, 46-49].

And, finally, the concept of conformational fingerprinting of ACE using mAbs [50] was formulated, which in turn allowed to prove the tissue specificity of ACE, which seems to have very large scientific and, at least, diagnostic prospects.

Since conformational fingerprinting can be applied to any protein-antigen, to which $\mathrm{mAbs}$ to different epitopes were generated, the concept of tissue specificity can also be applied to any glycoprotein. Therefore, we will discuss this concept in more detail.

\section{CONFORMATIONAL FINGERPRINTING OF ACE}

During these $30+$ years my lab generated and characterized more than $40 \mathrm{mAbs}$ directed to sequential epitopes (recognizing linear parts of the polypeptide chain) as well as conformational (discontinuous) epitopes on ACE of human, rat, mice and other species $[30,32,34-36,51-53]$. These mAbs were successfully used for ACE quantification using ELISA [18], flow cytometry [11, 50, 54], Western blotting [34, 38], and inmmunohistochemistry [55]. In all these applications only single $\mathrm{mAb}$ (once-two mAbs [46]) was used. However, it gradually became clear that a fundamentally new information on the structure and functioning of the ACE can be obtained if to use a whole set of mAbs - to different epitopes.

When we finished epitope mapping or mAbs on the ACE molecule, we noticed that all $16 \mathrm{mAbs}$ directed to 
Epitopes of mAbs on the surface of ACE

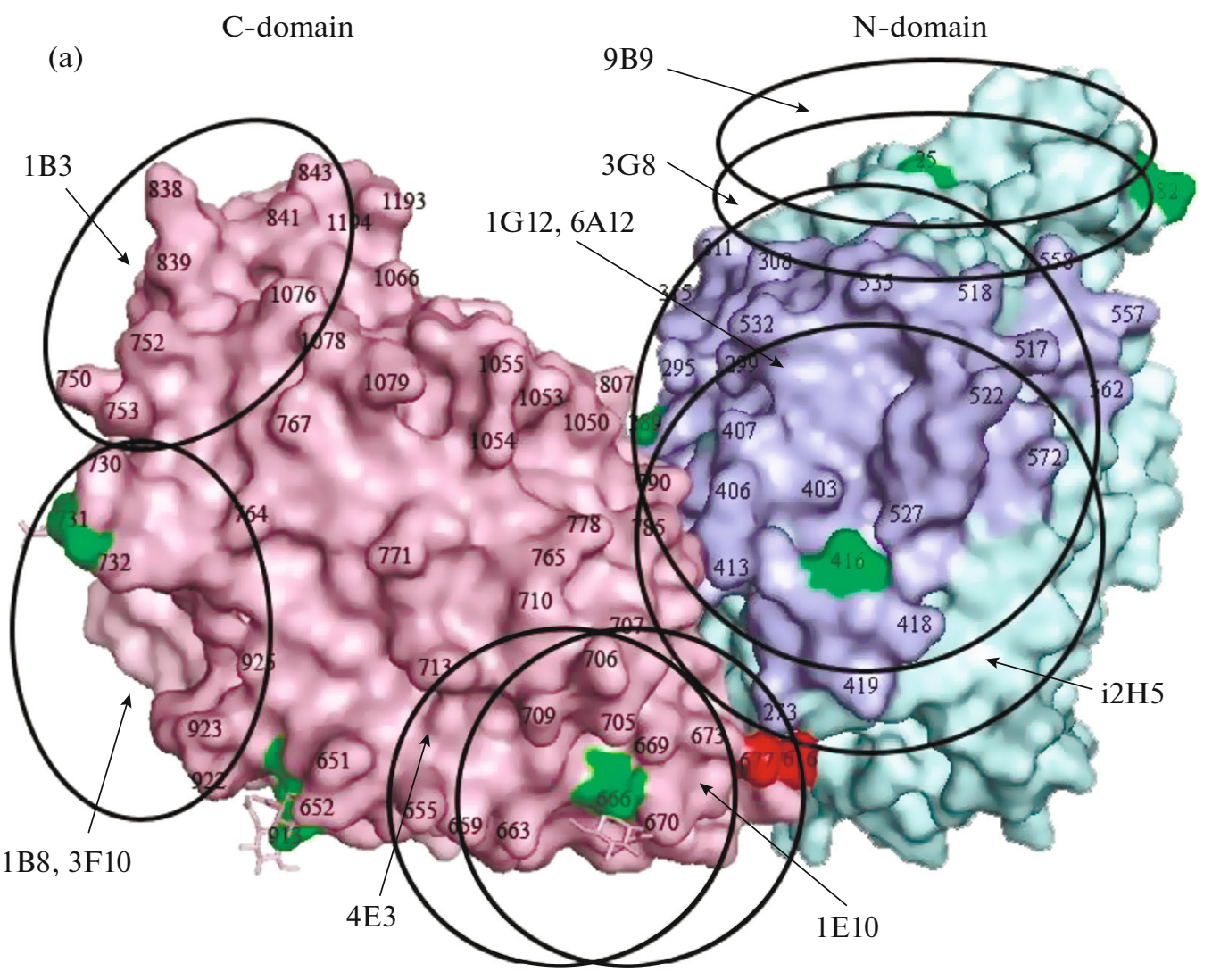

(b)

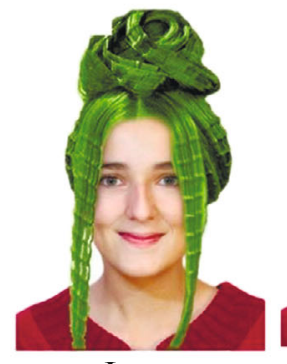

Lung

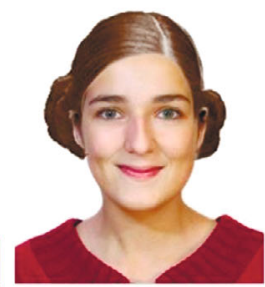

Liver

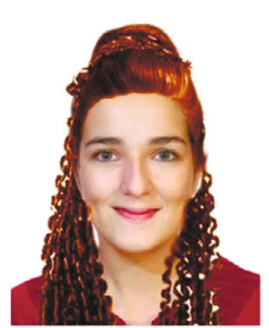

Prostate

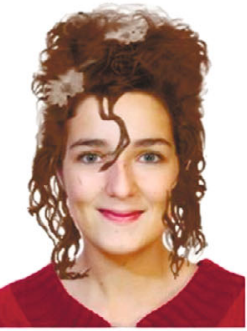

Heart

Fig. 1. Conformational fingerprinting of ACE. (a) Epitopes of mAbs to ACE contain potential glycosylation sites. The model of the mutual arrangement of $\mathrm{N}$-and $\mathrm{C}$-domains within the two-domain somatic ACE was based mainly on the results of mapping the epitopes of mAbs 1G12 and 6A12 on the N-domain (blue) and mAb 1 E10 and 4E3 on the C-domain. The region of epitopes is shown by circles with a diameter of about 25-30 $\AA$, which corresponds to an area of $600-900 \AA^{2}$. Most epitopes contain potential glycosylation sites-colored green (the pattern is adapted from Fig. 1 in [50]). (b) Diagram illustrating the concept of conformational fingerprinting of ACE. The identical face of the girl in all the pictures reflects the presence of one gene that encodes the amino acid sequence of an ACE molecule in different organs (and cells) of a human. Different hairstyles mean that the glycosylation of ACE in different organs and cells can differ significantly, which leads to differences in the local surface conformation of ACE in different organs and cells.

conformational epitopes of human ACE contain potential glycosylation sites (Fig. 1a), which in the ACE molecule are 17 (10 in the N-domain and seven in the C-domain [24]. Since the combined work of more than 100 genes is responsible for the glycosylation of human proteins [56], it could be assumed (and experimental evidences were obtained) that the combined expression of these genes (and hence the glyco- sylation of the same protein) should differ in different organs [57]. This can be schematically represented as follows: the ACE gene encoding the amino acid sequence of the protein is the same in all organs (like my daughter's face), whereas the set of sugars (glycans) decorating various ACE glycosylation sites (and hence the surface conformation of the ACE) is different in different organs (as well as my daughter's hair, Fig. 1b). 
Using a set of $16 \mathrm{mAbs}$ to different epitopes on both domains of ACE we demonstrated that a pattern of binding of these $\mathrm{mAbs}$-conformational fingerprint of ACE was different for human recombinant ACE expressed in different cells ( $\mathrm{CHO}$ vs $\mathrm{HEK}$ ) or in the same $\mathrm{CHO}$ cells, but at different culture conditions or for ACE from different native human cells-endothelial cells versus macrophages [50]. When we performed ACE phenotyping at different diseases we also found that the conformation of ACE, synthesized in vivo in different organs/tissues also differ.

According to my rough estimates, under normal conditions, approximately $75 \%$ of ACE in the blood plasma derived from the endothelial cells of the lung capillaries. This estimation is based on the facts that (1) $30 \%$ of all capillaries localized in the lung [58]; (2) almost $100 \%$ of lung capillaries are expressed ACEin a sharp contrast to capillaries in systemic circulation, where only $10-15 \%$ of ACE-positive capillaries were found [9].

As I already mentioned, in healthy donors the level of ACE in the blood is quite stable, whereas in sarcoidosis or Gaucher disease there is a significant increase in the level of ACE in the blood (2-5 fold). Sarcoidosis is a systemic granulomatous disease which characterized by granuloma formations at first in the lungs, and then, during generalization of the process-in the lymph nodes, heart, liver, spleen and even neural system. In the organs with granulomas the ACE levels (both activity and protein) increased up to $10-15$ fold [59]. It is sarcoid granulomas that are the source of a high content of ACE in the blood. Thus, during the development of these diseases in the blood, in addition to the ACE coming from the endothelial cells of the lung, an enzyme produced by macrophages and dendritic cells (Fig. 4 in [50]) will be present, the surface conformation of which may be different.

Analysis of binding of mAbs to ACE in the plasma of patients with sarcoidosis (the level of ACE activity was increased 2-4 times compared to the norm) and in healthy donors revealed differences in binding of several mAbs. Namely, in sarcoidosis a higher statistically significant binding of $\mathrm{mAb} 3 \mathrm{G} 8,1 \mathrm{G} 12$ and $6 \mathrm{~A} 12$ to the enzyme N-domain, as well as mAb 1B3, 1E10 and $3 \mathrm{~F} 11$ to the $\mathrm{C}$-domain is observed (Fig. 2a). The differences in the conformation of ACE from the lungs and lymph nodes in patients with sarcoidosis and in the control group were even more pronounced (Fig. 5 in [50]).

Similar study was performed with ACE from plasma and tissues of patients with Gaucher disease, which plasma ACE levels was increased 3-5-folds. This disease is characterized by activation of macrophages (and dramatic increase of ACE expression in these cells) in the spleen [16] and liver (our unpublished data). The binding of the most mAbs to the blood ACE in this pathology does not change, but there is a statistically significant change in the binding of mAb 3G8 and 6A12 (N-domain ACE) and mAb 3F11 (C-domain ACE) (Fig. 2b). In these both diseases the source of increased levels of ACE in the blood is activated macrophages. However visible and significant changes in conformational fingerpint of ACE (Fig. 2) confirmed the concept of the tissue specificity of ACE: even ACE produced by the same cells (macrophages) but in different organs (or upon different diseases-sarcoidosis versus Gaucher disease) has different surface conformation.

We also analyzed the possibility of the presence of conformationally altered ACE in the blood of patients with uremia, a disease characterized by an extremely high level of toxins in the blood. It turned out that even in this case the binding efficiency of two mAbs with plasma ACE of uremic patients differed from the efficiency of binding these mAbs to ACE from plasma of healthy donors. There were statistically significant differences in the binding efficiency of $\mathrm{mAb} 1 \mathrm{G} 12$ to the $\mathrm{N}$-domain and $\mathrm{mAb} 1 \mathrm{~B} 3$ to the $\mathrm{C}$-domain of the enzyme in four patients out of 20 (Fig. 3 in [45]). Changes were affected not only the surface of the protein, but also affected its catalytic functions. It turned out that the conformationally altered ACE is characterized by an increased (up to 4 times) activity with respect to the natural substrate angiotensin I, less efficiently inhibited by a specific ACE inhibitor enalaprilat (tripeptide analogue widely used as an antihypertensive agent) and practically was not inhibited by another ACE inhibitor-nonapeptide teprotide. We also analyzed a large sample of blood plasma from healthy donors [48] and patients without uremia [62] and found eight cases of the same conformationally altered ACE as with uremia-which are less susceptible to specific ACE inhibitors [45]. Thus, patients with such conformationally altered ACE in their blood should probably be given more intensive therapy with ACE inhibitors, or replace them with antihypertensive agents of another class.

Our pilot studies on the ACE phenotyping in different tissues and in various human diseases have shown that the pattern of binding of mAbs set directed to different epitopes on the surface of the ACE differs both in the case of ACE from different tissues and in different diseases. The obtained data allow to conclude that there are also differences in the local conformation of the ACE surface produced by various tissues/cells.

What can be the nature of these differences? First of all, differences on the surface of the enzyme may be due to the replacement of amino acid residues in its polypeptide chain. However, the ACE is encoded by a single gene, and the currently known mutations affecting the protein portion of the ACE are quite rare and can in no way be related to differences in the surface of the enzyme in different tissues of the same individual.

It is much more likely that the observed differences are due to post-translational modifications of the pro- 


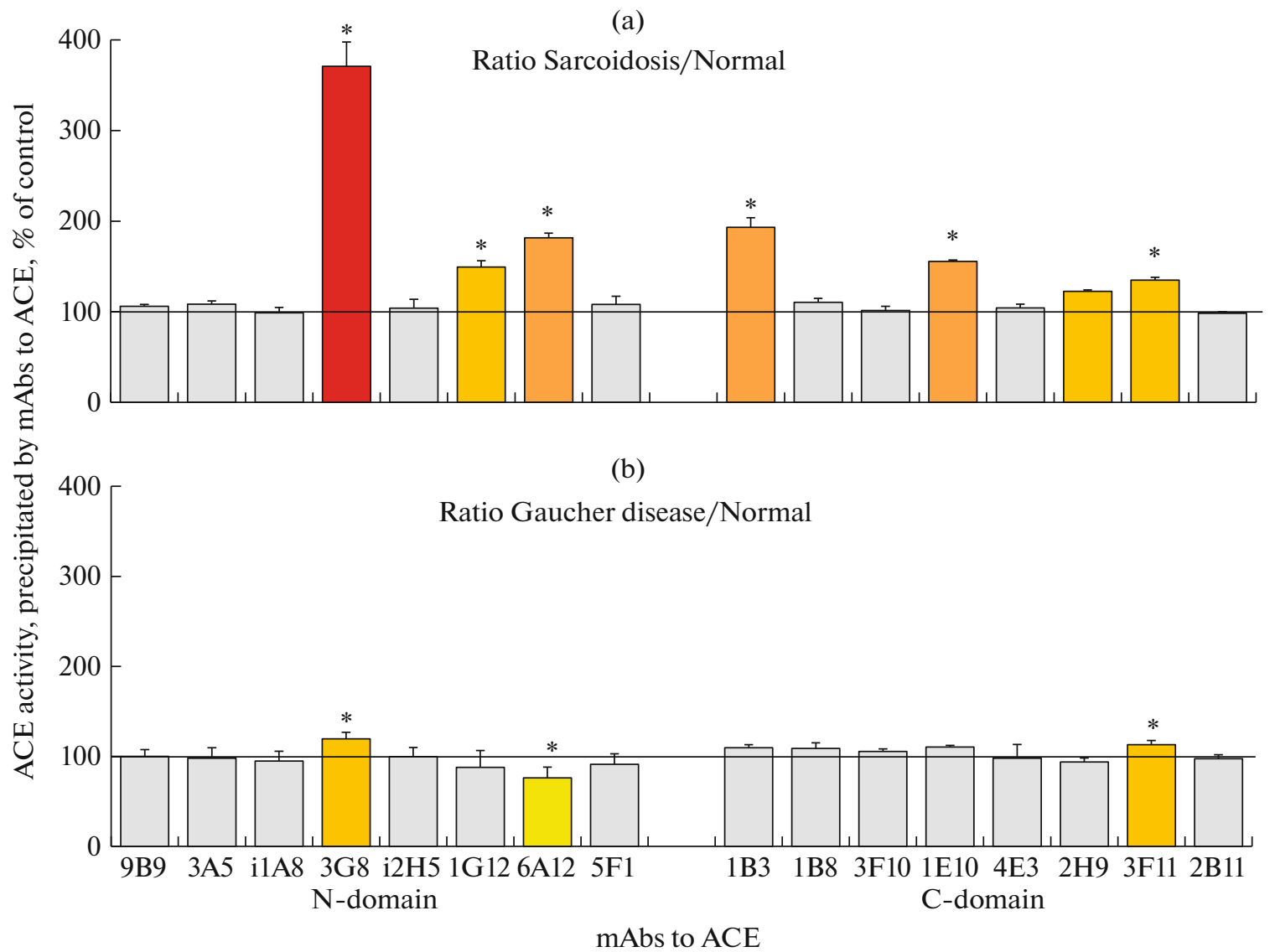

Fig. 2. Conformational fingerprinting of blood ACE. ACE from the blood plasma was precipitated onto the surface of a 96-well microtiter plate using 16 mouse mAbs to various epitopes of human ACE, which were immobilized in the wells via affinity purified goat anti-mouse IgG. The activity of the precipitated ACE was measured directly in the well after washing unbound ACE and incubating with ZPHL, an ACE substrate [30]. This activity is presented as a normalized value-the ratio of ACE activity precipitated from the plasma of patients to the ACE activity from the plasma of healthy individuals (taking into account the different activities introduced). (a) Pool from four patients with sarcoidosis (against a pool of five control plasma samples) was used to evaluate the conformation of ACE in sarcoidosis (adapted from Fig. 7 in [50]). (b) Pool from 10 plasma samples of patients with Gaucher disease (against a pool of seven control samples) was used for the same purpose in the case of Gaucher disease (adapted from Fig. 2 in [60]). The data are presented as the mean value, determined from the results of at least three measurements in the case of antibodies, binding of which to ACE from patients changed less than $20 \%$ compared to the control (grey bars), and 8-12 measurements if the changes exceeded $20 \%$ (colored bars). This ratio ("binding ratio") when it increases by more than $20 \%$ of the norm is colored orange, $50 \%$ light brown, $100 \%$ red, while a decrease of more than $20 \%$ is shown in yellow. Asterisks marked statistically significant differences, $p<0.05$.

tein globule, which, figuratively speaking, is "functional decorating," i.e. "Decoration with meaning." Post-translational modifications may include phosphorylation, sulfation, methylation, acetylation, etc. [63]. But for a protein such as ACE, a typical glycoprotein with a high carbohydrate content, this post-translational modification is primarily glycosylation, which can differ in proteins synthesized in different tissues, both in degree and structure.

It is most likely that ACE produced by lung tissue, as well as by altered macrophages in Gaucher's disease or sarcoid granulomas in sarcoidosis, differ in the nature of glycosylation. The epitope of mAb $3 \mathrm{G} 8$ (binding of which to the blood ACE is altered both for Gaucher's disease and for sarcoidosis, Fig. 2) contains two potential glycosylation sites-Asn 25 and Asn 82 on the enzyme N-domain [42]. Epitopes of $\mathrm{mAb}$ whose binding efficiency is altered in sarcoidosis contain the following potential glycosylation sites: Asn416 (mAb $1 \mathrm{G} 12$ and 6A12) on the N-domain, as well as Asn666 (mAb 1E10) and Asn1196 (mAb 1B3) on the C domain. Thus, it can be concluded that differences in the degree of glycosylation and/or the structure of oligosaccharide chains in these sites are the basis of differences in mAbs binding to blood ACE in normal and with the development of these pathologies.

Direct evidence of differences in the glycosylation of ACE, synthesized in different cells and organs, was obtained by comparing the conformation of the ACE from the seminal fluid (produced by the epithelial cells of the prostate and epididymis) and the lung ACE (produced by the capillary endothelial cells) [62]. The 
Conformational fingerprinting of ACE from different organs

(a)

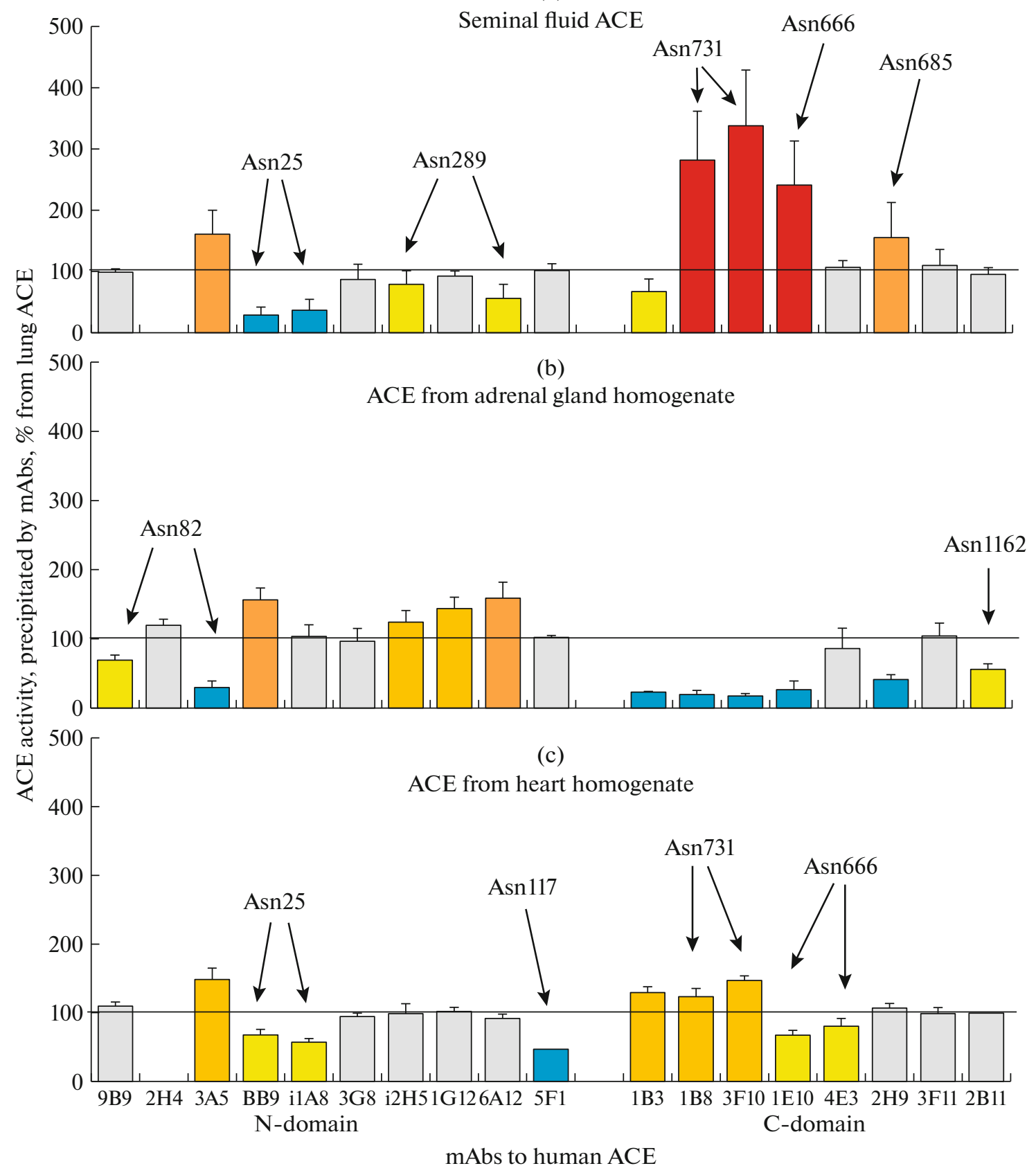

Fig. 3. Conformational fingerprinting of ACE from different organs. ACE activity in purified ACE preparations from the seminal fluid (a) and the heart (c), as well as from the adrenal homogenate (b), was precipitated and presented as in Fig. 2. Reduction in the ratio (precipitation of ACE activity from this organ to ACE activity from the lung preparation- "binding ratio") is shown in blue more than $50 \%$ of the norm. (Part a is adapted from Fig. 1a [62], part $\mathrm{c}$ is from Fig. 3 [65]).

binding of $10 \mathrm{mAbs}$ (out of 17 tested) to the ACE from the seminal fluid was different from binding to the ACE from the lung (Fig. 3a).

Mass spectrometry analysis of tryptic fragments of ACE from these preparations revealed differences in glycosylation of sites located in epitopes of mAbs, which were differently bound to these ACEs (Table 2 in [62] and Fig. 4). Further confirmation of the differ- ent conformation of ACE expressed in different tissues (i.e., tissue specificity of ACE) was obtained by analyzing the conformation of the ACE from the adrenals, the tissue which is of neuronal origin (Fig. 3b), and the ACE from the heart (Fig. 4c), which is produced not only the capillaries of the heart, but also myofibroblasts [64], in contrast to the ACE of the lung (produced only by capillaries [9]). 
Glycosylation of Human ACE
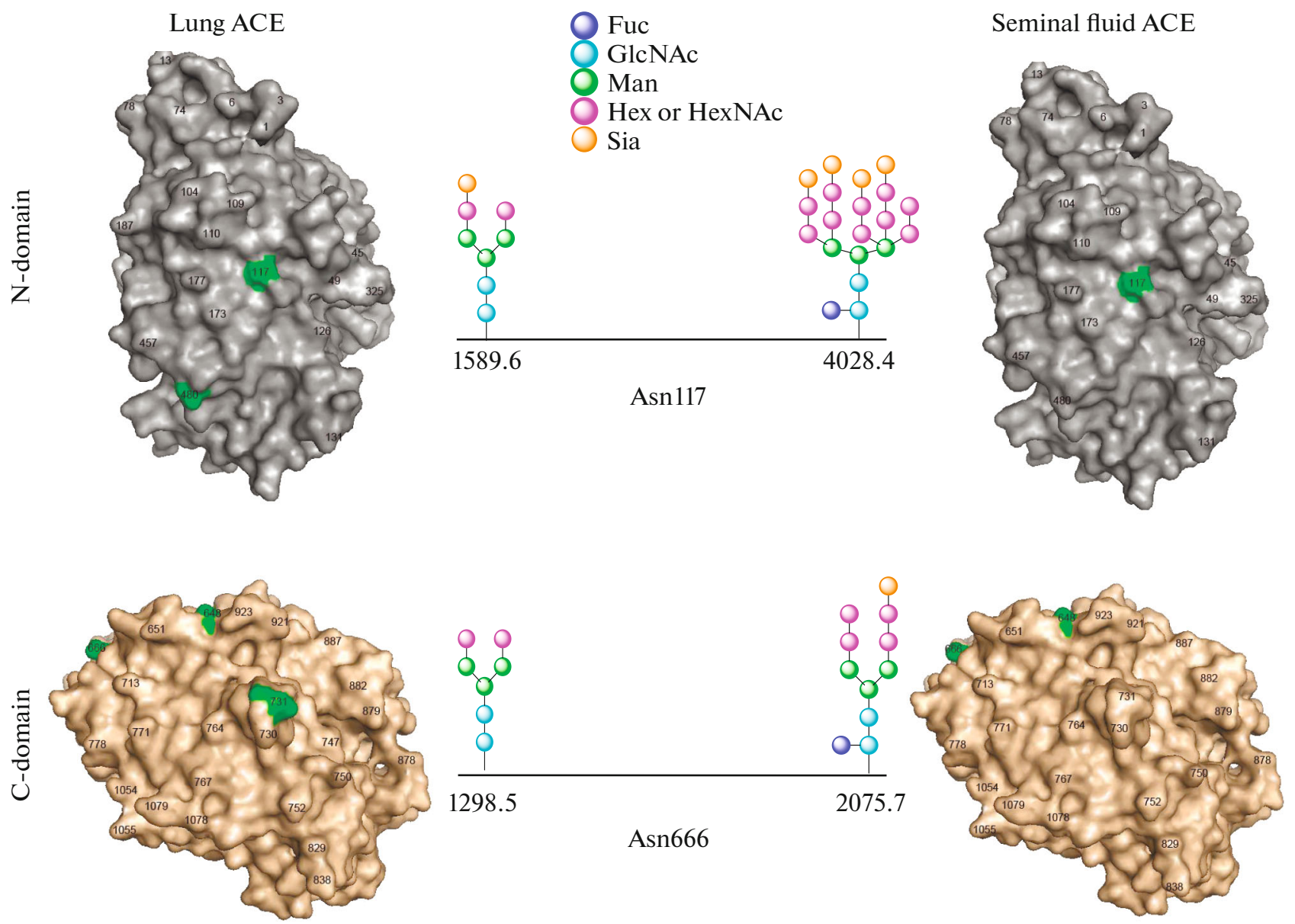

Fig. 4. Differences in glycosylation of ACE from different organs. Differences in glycosylation of ACE from seminal fluid and lungs, revealed by mass spectrometry of their tryptic fragments and presented in Table 2 in [62] are shown graphically. Asn480, glycosylated in the N-domain of the ACE of the lung (isolated in green), is not glycosylated in the ACE of the seminal fluid (like Asn731 in the C-domain of the ACE of the lung), whereas Asn117 in the ACE N-domain and Asn666 in the ACE C-domain glycosylated differently in the ACE from the lung and seminal fluid.

Thus, there is a structural base for tissue specificity of ACE (different glycans in some glycosylation sites of ACE in different organs), which opens up the theoretical possibility of obtaining $\mathrm{mAb}$ specific for the ACEs from different organs. During pilot immunization of mice with ACE purified from seminal fluid, we found lymphocytes which produce antibodies that discriminate lung ACE and ACE from seminal fluid (Fig. 7 in [62]). Therefore, with a systematic approach, it is possible to obtain such discriminating antibodies.

Are there any practical benefits from antibodies specific for ACE from different organs? Indeed, in our opinion, since such antibodies will allow to quantify the amount ACE in the blood coming from different organs, the proportion of which can vary with the pathology of these organs. The first example of the use of "conformational fingerprinting" of ACE is cardiology, which we are currently developing together with the groups of Elena Golukhova (Bakulev Center for
Cardiovascular Surgery, Moscow, Russia) and Olga Kost (Moscow University, Russia).

In 2000 it was established (with the help of our $\mathrm{mAb} 5 \mathrm{~F} 1$ ) that expression of ACE is increased in the heart tissues and, in particular, in the atria in atrial fibrillation [66]. It was also previously shown that ACE expression is elevated in the hypertrophied heart and small vessels of the myocardium in suddenly died patients (Bohle, Franke, Metzger, Danilov, et al., unpublished). An important role of the heart ACE in the development of cardiac pathology was also revealed in studies on transgenic mice in which the level of ACE expression in the heart tissues was 100 times higher than normal. In these mice, both atria (left and right) were enlarged 3-fold, and an electrocardiographic study revealed atrial fibrillation. Moreover, these mice had a high predisposition to sudden death [67]. Thus, the increase in the ACE expression in the heart can cause 


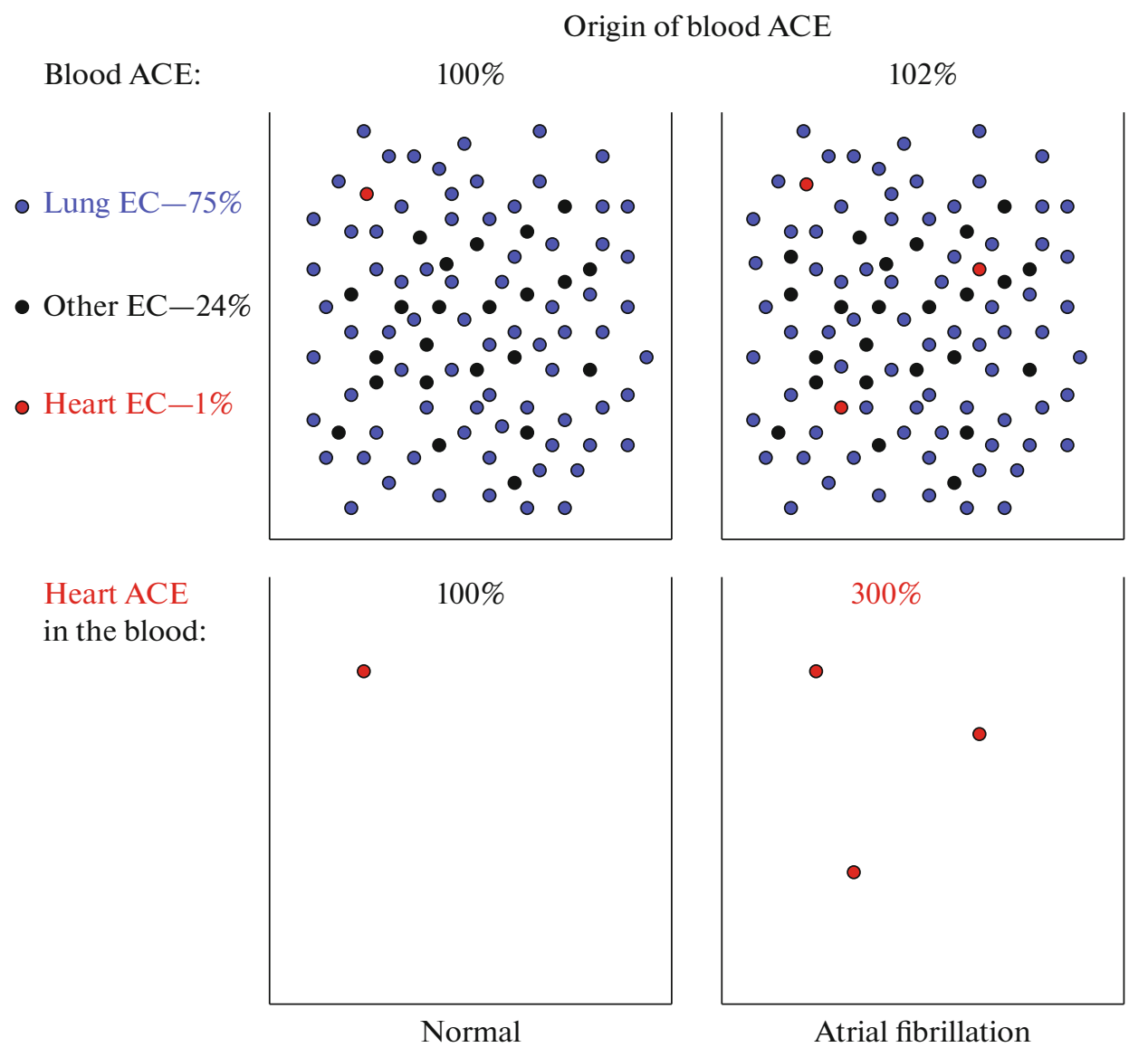

Fig. 5. Influence of atrial fibrillation on ACE activity in the blood. According to our estimates, the blood ACE is represented by $75 \%$ of the ACE that is "cleaved" from the surface of the endothelial cells (EC) of the lung capillaries, while the percentage of ACE that has entered the blood from the heart is hardly more than 1\%. In this case, with an increase in ACE expression 3-fold in atrial fibrillation [66], the ACE activity of the blood can increase by more than $2 \%$, which cannot be detected by any clinical test, since ACE activity in the population varies 3-4 times [13, 18]. However, if to generate mAbs specifically "recognizing" only ACE from the heart, a threefold increase in the activity of such ACE in patients at risk of developing atrial fibrillation may become a trivial task. The figure is adapted from Fig. 9 in [65].

the development of atrial fibrillation and, ultimately, lead to sudden death.

According to our estimates, the percentage of ACE coming from the heart in the total ACE in the blood does not exceed $1 \%$. Thus, even an increase in the ACE from the heart in the blood 3 times cannot significantly affect the overall ACE activity in the blood. However, the percentage of ACE of the heart that "comes" into the blood and "supplement" the ACE that enters the blood from the lungs can be assessed and thus revealed patients with increased expression of ACE in the heart if to have antibodies specifically "recognizing" only the ACE of the human heart (Fig. 5).

The efficacy of mAbs binding to both the $\mathrm{N}$ - and $\mathrm{C}$-domains of heart ACE is statistically significantly different from the binding efficiency of the same mAbs to the lung ACE. These differences can primarily be attributed to differences in the glycosylation of the following potential glycosylation sites: Asn 25 on the enzyme N-domain, as well as As666 and Asn731 on the C-domain (Fig. 3c). The revealed differences can serve as the basis for obtaining mAbs specifically recognizing ACE produced by the heart tissues, for further development of the clinical method for early arrhythmia diagnostics.

It is very likely that such tissue-specific antibodies against ACE may be suitable for early detection of cancer in a given organ. Normally, ACE produced in the depth of tissue by cells other than endothelial cells (for example, cells of sarcoid granulomas in the lungs or prostatic epithelial cells) does not enter the blood. Therefore, in lung only sarcoidosis, the content of ACE in the blood is not increased [68], despite its huge concentration inside the granuloma (Fig. 4 in [50]) as well as an increase in the ACE activity in the seminal fluid by 50 times compared with the concentration in the blood [69]. With the development of the tumor process in the organs, the expression of VEGF sharply increases [70, 71], which, in addition, dramatically increases the permeability of capillaries in tumor tis- 
sue through an increase in endothelial fenestration [72]. It can be expected that an ACE synthesized in the depth of an organ affected by a tumor will appear in the blood, where it will be detected by an antibody specific for the ACE of this organ.

Together with Marcin Paduch and Anthony Kossiakoff (University of Chicago, USA) and Olga Kost (Moscow University, Russia), we were able to select from the synthetic phage library Fab fragments of human origin, predominantly binding to the pulmonary ACE, and literally a couple of months ago, together with the Isolda Popova (Northwestern University, Evanston, USA) and Alex Lyubimov (University of Illinois at Chicago, USA) and Olga Kost (Moscow University, Russia), we obtained $\mathrm{mAb}$ specific for ACE from epithelial cells (and, in particular, the epithelium of the prostate that does not "recognize" the ACE of the lung (unpublished data)).

\section{TARGETED DRUG/GENE DELIVERY INTO THE LUNG ENDOTHELIUM USING MONOCLONAL ANTIBODIES TO ACE}

The initial goal of the project was to obtain mAbs against the organ-specific endothelium, which can be used for targeted drug delivery to different organs. One of the mAbs against ACE, obtained in the first series (9B9), recognized not only human ACE, but also rat ACE [32] (and also hamster and cat ACE, although to a much lesser extent [30], which allowed to trace this $\mathrm{mAb}$ after intravenous administration. We found (together with Vladimir Muzykantov) that radioactively labeled mAb 9B9 is extremely effective (up to $50 \%$ of the administered dose [73] and specificity (30-50 times more than in other organs and blood) accumulate in the lung [74-76]. Later we mapped the epitope for mAb 9B9 [42] and also determined the reason for such specific accumulation of mAbs to ACE in the lung. The fact is that $100 \%$ of the capillaries of the lungs express ACE (versus 5-15\% of the ACE-positive capillaries in the systemic circulation) [9], whereas in healthy kidneys neither the glomerular endothelium nor the intercellular endothelium produce ACE in general [9]. Such heterogeneous expression of ACE along the vascular bed with preferential expression in the capillaries of the lung provides a specific accumulation of antibodies in the lung during systemic administration.

Over the past 30 years, many attempts have been made to use mAbs for other endothelial antigens to deliver drugs/genes to the lungs [77], but the most successful combination of specificity and efficacy have shown $\mathrm{mAb}$ against ACE [76]. So, in addition to $\mathrm{mAbs}$ against ACE (CD143), when isolated lungs are perfused in capillaries, mAbs against endothelial antigensPECAM-1 (CD31), ICAM-1 (CD54), Thy-1.1 (CD90.1) and OX-43 are also specifically and efficiently accumulated. However, with systemic admin- istration, only mAb against ACE specifically accumulates in the lung [76].

MAb against aminopeptidase $P$ accumulates in the lung with systemic administration even more specifically than mAb against ACE (lung/blood ratio is 124 for $m A b$ 833c [78] versus 23 for mAb 9B9 [73]), so it can be used for gamma-scintigraphy of lung capillaries [78] (along with mAbs against ACE [74, 75]. However, the expression of aminopeptidase $\mathrm{P}$ in lung capillaries, although very specific, is very low (in comparison with the amount of ACE expressed in human lungsapproximately $20 \mathrm{mg}$, according to our estimates), which does not allow the use this mAb (833c) for the delivery to the lung therapeutically significant amounts of drugs (proteins, genes, small molecules, particles).

Another remarkable advantage of ACE as a target for drug delivery to the lung (and mAbs against ACE as a vector) is a very low level of ACE expression in the liver capillaries [9]. The point is that the "immediate" accumulation of viruses or the liposomes (the main carriers of the gene material in gene therapy) in the liver during systemic administration presents a huge problem for the targeted delivery of the gene material (in liposomes or viruses coated with specific antibodies) to other organs. Excessive accumulation of adenoviruses in the liver even caused the death of one of the first patients subjected to gene therapy in 1999 [79]. When we "coated" (using a bispecific reagent) adenoviruses with $\mathrm{mAb}$ against $\mathrm{ACE}$ (9B9), we found not only a 20 -fold increase in the specific accumulation of such "targeted" viruses in the lung, but also a 5-fold decrease in the accumulation of viruses in the liver [80]. Thus, the specific accumulation of gene material in the lung increased by a factor of 100 compared with accumulation in the liver (Fig. 6).

We thoroughly studied the phenomenon of accumulation of mAbs against ACE (more than 30 publications) and developed effective methods of delivering therapeutic proteins $[81-85]$ and genes $[80,86]$ to the lung endothelium, and in various experimental models showed a stable therapeutic effect of such gene delivery [87-90].

Delivery of antioxidant enzymes to the lung capillaries (to prevent oxidative damage to the lungs as a result of ischemia) could dramatically increase the percentage of suitability for the transplantation of an immunologically compatible donor lung after transportation. Currently, the percentage of lung going to transplantation after transportation is only $20 \%$ [91], compared with $95 \%$ for the heart and kidneys. In addition, this approach can be used in acute respiratory failure (ARDS) caused by acute oxidative damage to the lung. Injection of catalase, conjugated with antiACE antibodies, sharply increased the resistance of rat lungs to various oxidative damage models [82-85].

Delivery to the lung capillaries of a nitrogen synthase (NOS) gene prevented an increase in blood pressure in the vessels of rats with spontaneous hyperten- 


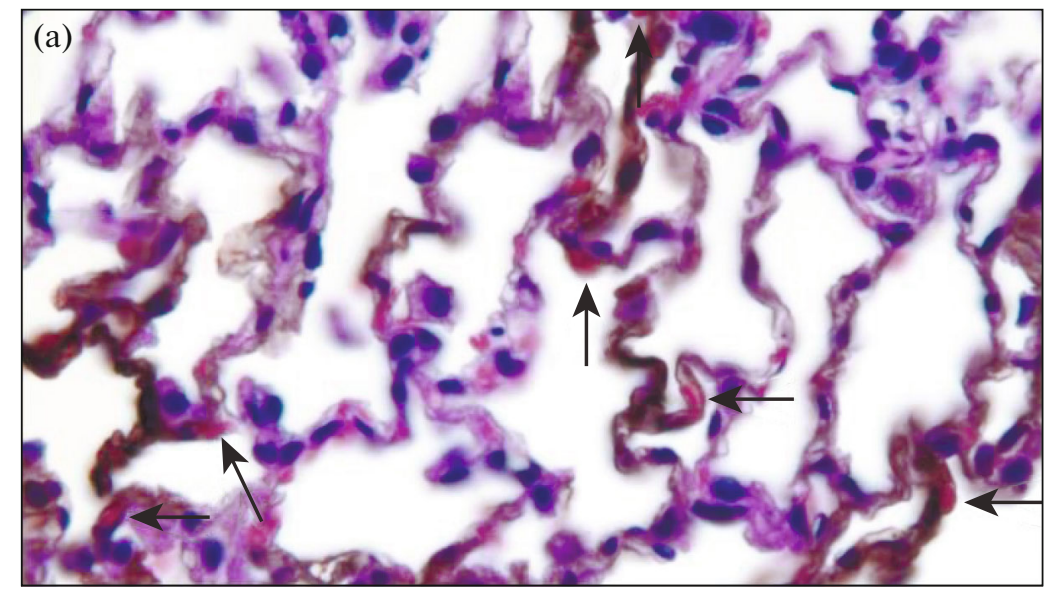

(b)
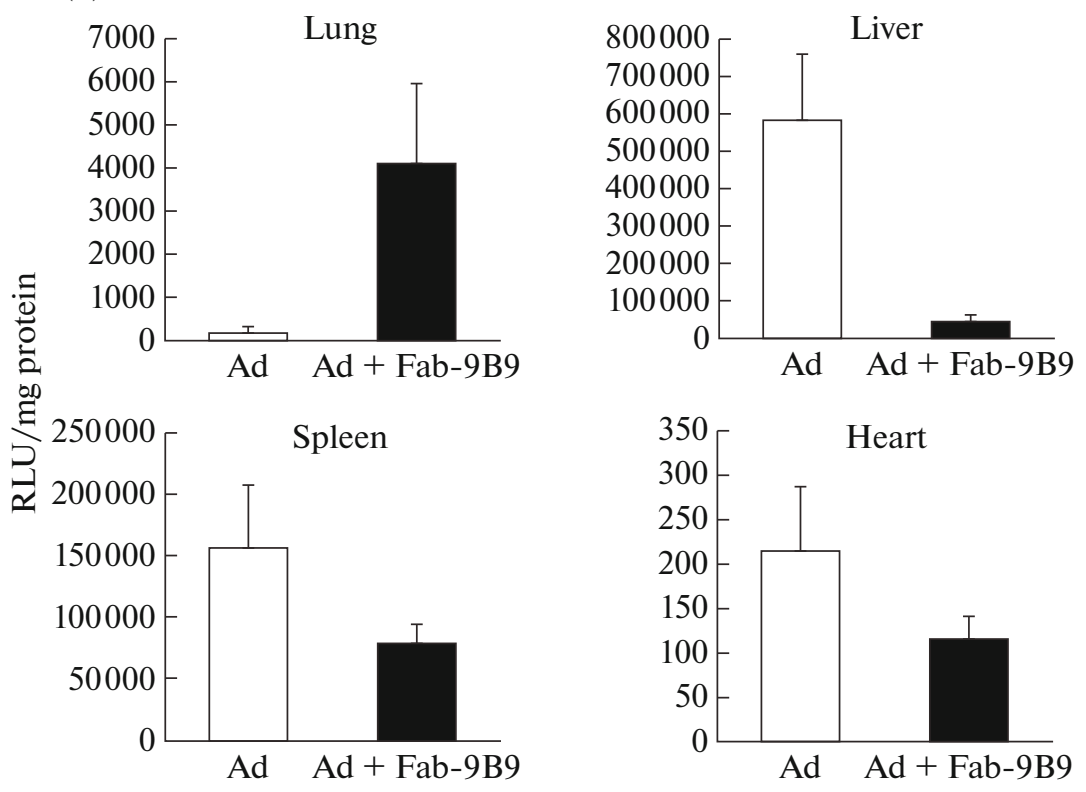

Fig. 6. Specificity of delivery of reporter transgene into the lungs via mAb to ACE. (a) Rat lungs transfected in vivo with adenoviruses with a reporter transgene (CEA) and "coated" with mAbs against ACE are stained with antibodies against CEA. Expression of the transgene (brown staining), was absent in the lungs of rats transfected with viruses with transgene, but not "coated" with anti-ACE mAb (adapted from Fig. 6a in [80]). (b) The activity of the reporter gene (luciferase) was evaluated in different organs of the rat 3 days after adenovirus adenovirus administration (AdCMVLuc $\left(2 \times 10^{9} \mathrm{pfu}\right)$ ) and expressed through luciferase activity (RLU), normalized to $1 \mathrm{mg}$ protein. The mean values of three experiments + SEM (adapted from Fig. 4a in [80]) are presented. Expression of the reporter gene from the virus, "coated" with mAb against ACE, increased in the lungs by 20 times (upper left graph) and decreased in the liver 5 times (upper right graph).

sion [87] and the delivery of the bone morphogenetic protein receptor gene $(B M P R 2)[88,89]$ or endothelial Thp1 [90] reduced the development of pulmonary hypertension in rat models of hypoxia. Delivery to the donor lung endothelium of the genes, the expression of which prevents the rejection reaction of the transplant, could be useful in lung transplantation.

Despite examples of the successful use of mAbs against ACE, chemically conjugated with therapeutic proteins or with $\mathrm{mAbs}$ against adenovirus surface protein (knob), it was clear that to further develop this approach, and especially its possible clinical applica- tion, it is necessary to clone the gene of antibody against ACE in order to use subsequently genetic engineering methods for conjugation with with therapeutic proteins (fusion proteins) or with proteins of the surface of viruses, or with the surface of nanoparticles.

It should be noted that the fantastic success of the use of mAbs in the clinic (primarily oncology) is associated with the development of genetic engineering methods for cloning and expression of $\mathrm{mAb}$ genes, the production of functional fragments of antibodies (Fab, scFv, monobodies, diabodies, etc.) and various conjugates, including bispecific antibodies-what is 
now called Antibody Engineering ([92] (see also articles from this issue [Nedospasov, etc.]).

We were able to clone the genes of heavy and light chains of the most used mAb 9B9 and get its fragment $(\mathrm{scFv})$. However, the binding affinity of this fragment fell by two orders of magnitude [93]. Nevertheless, our results allow us to hope for successful clinical application of this approach, which is impossible, however, when using $\mathrm{mAb}$ of mouse origin. The fact is that the production of the first antibodies (especially to tumor antigens) gave rise to an extraordinary revival in the biomedical and biotechnological world, since it seemed that a "magic bullet" was about to appear to treat cancer. However, pretty soon it became clear that mouse mAbs cannot be used as therapeutic, as injections of such mAbs lead to a significant production of antibodies against mouse immunoglobulinsHuman-Anti-Mouse Antibodies (HAMA) response. Therefore, in the 1980s, various approaches were developed to "humanize" mouse mAbs and to obtain antibodies using "humanized" mice [94].

An alternative to the "mouse" approach to obtaining $\mathrm{mAbs}$ suitable for clinical (including therapeutic) use was the development of phage synthetic libraries containing fragments of antibodies expressed on the surface of phage M13. Therefore, together with Marcin Paduch and Anthony Kossiakoff (University of Chicago, USA) and Olga Kost (Moscow University, Russia), we launched a project for the selection of humanderived Fab fragments against human ACE from a very representative $\left(10^{10}\right.$ variants) synthetic phage library based on the famous antibody, Herceptin [95]. At present, 16 non-identical phages bearing highly affinity (about $20 \mathrm{pM}$ ) Fab fragments of human origin against human ACE that are suitable for clinical application-the delivery of therapeutic proteins and/or genes to human capillaries-have been selected.

\section{CONCLUSIONS}

(1) The studies of ACE using mAbs to ACE have shown that the "pattern" (conformational fingerprint) characterizing the binding efficiency of a mAb set directed to different epitopes on the surface of both ACE domains is an extremely sensitive marker of changes in the local conformation of the enzyme (e.g., by denaturation, inactivation, binding of inhibitors, antibodies and various mutations). Since the binding epitopes of all mAbs from this set have already been characterized, it is possible to judge from the change in the binding of one or another mAb to the ACE which area of the protein surface has undergone changes.

(2) Phenotyping of human ACE from different tissues and organs convincingly showed that the mAbs set directed to different epitopes on the surface of the ACE, differently binds to the ACE. This means that the conformation of the surface of the ACEs expressed by different tissues/cells also differs.
(3) The observed differences are due to post-translational modifications of ACE, which may include phosphorylation, sulfation, methylation, acetylation, etc. But for ACE, a typical high-carbohydrate glycoprotein, this post-translational modification is primarily glycosylation, which is different for proteins synthesized in different tissues, both in the degree of glycosylation, and in the structure of glycans.

(4) Tissue specificity of ACE, revealed by conformational fingerprinting, creates a structural base for the generation of mAbs specific for ACE from different organs, which, in turn, can dramatically expand diagnostic capabilities.

(5) The generation of mAbs to the maximum number of epitopes of the given glycoprotein greatly enhance a possibility of a structural and functional study of this protein. The concept of conformational fingerprinting using a wide panel of mAbs is certainly applicable to the study of a wide variety of proteins.

\section{ACKNOWLEDGMENTS}

When we started this project, the attitude towards it was more than critical, in particular, because only a few laboratories in the world used this approach. With special proud I want to note that one of these laboratories was laboratory of respected Garry Abelev (Russian Cancer Center, Moscow), where more than $50 \mathrm{mAbs}$ to alpha-fetoprotein was analyzed using the new approach to study the structure and functions of this important cancer marker [96].

I express my sincere gratitude to both the key colleagues mentioned in this article and to all colleagues/co-authors of the articles published on this topic, without whose participation the implementation of this project would be impossible.

This project is partially supported by a grant from the Ministry of Education and Science of the Russian Federation (Mega Grant 14.Z50.31.0026) and was carried out (partially) within the state assignment of Moscow University (Russia).

\section{REFERENCES}

1. Köhler G., Milstein C. 1975. Continuous cultures of fused cells secreting antibody of predefined specificity. Nature. 256, 495-497.

2. http://www.whatisbiotechnology.org/exhibitions/milstein/patents.

3. Auerbach R., Alby L., Morrissey L.W., et al. 1985. Expression of organ-specific antigens on capillary endothelial cells. Microvasc. Res. 29, 401-411.

4. Allikmets E.Y., Danilov S.M. 1986. Mitogen-induced disorganization of capillary-like structures formed by human large vessel endothelial cells in vitro. Tissue Cell. 18, 481-489.

5. Sturrock E.D., Anthony C.S., Danilov S.M. 2012. Peptidyl-dipeptidase A/angiotensin I-converting enzyme. In: Handbook of Proteolytic Enzymes, 3rd ed. Eds. Raw- 
lings N.D., Salvesen G. Oxford: Academic Press, pp. 480-494.

6. Bernstein K.E., Ong F.S., Blackwell W.L., et al. 2013. A modern understanding of the traditional and nontraditional biological functions of angiotensin-converting enzyme. Pharmacol. Rev. 65, 1-46.

7. Danilov S.M., Franke F.E., Erdos E.G. 1997. Angiotensin-converting enzyme (CD143). In: Leucocyte Typing VI: White Cell Differentiation Antigens. Eds. Kishimoto T. New York: Garland, pp. 746-749.

8. Dzau V.J., Bernstein K., Celermajer D., et al. 2001. The relevance of tissue angiotensin-converting enzyme: Manifestations in mechanistic and endpoint data. Am. J. Cardiol. 88, 1L-20L.

9. Metzger R., Franke F.F., Bohle R.-M., et al. 2011. Heterogeneous distribution of angiotensin I-converting enzyme (CD143) in the human and rat vascular systems: Vessels, organs and species specificity. Microvasc. Res. 82, 206-215.

10. Silverstein E., Friedland J., Setton C. 1978. Angiotensin-converting enzyme in macrophages and Freund's adjuvant granuloma. Isr. J. Med. Sci. 14, 314-318.

11. Danilov S.M., Sadovnikova E., Scharenbourg N., et al. 2003. Angiotensin-converting enzyme (CD143) is abundantly expressed by dendritic cells and discriminates human monocytes-derived dendritic cells from acute myeloid leukemia-derived dendritic cells. Exp. Hem. 31, 1301-1309.

12. Parkin E.T., Turner A.J., Hooper N.M. 2004. Secretase-mediated cell surface shedding of the angiotensinconverting enzyme. Protein Pept. Lett. 11, 423-432.

13. Alhenc-Gelas F., Richard J., Courbon D., et al. 1991. Distribution of plasma angiotensin I-converting enzyme levels in healthy men: Relationship to environmental and hormonal parameters. J. Lab. Clin. Med. 117, 33-39.

14. Lieberman J. 1975. Elevation of serum angiotensinconverting enzyme level in sarcoidosis. Am. J. Med. 59, $365-372$.

15. Lieberman J., Beutler E. 1976. Elevation of angiotensin-converting enzyme in Gaucher's disease. N. Engl. J. Med. 294, 1442-1444.

16. Silverstein E., Friedland J. 1977. Elevated serum and spleen angiotensin converting enzyme and serum lysozyme in Gaucher's disease. Clin. Chim. Acta. 74, 21-25.

17. Rigat B., Hubert C., Alhenc-Gelas F., et al. 1990. An insertion/deletion polymorphism in the angiotensin I-converting enzyme gene accounting for half the variance of serum enzyme levels. J. Clin. Invest. 86, 1343-1346.

18. Danilov S.M., Savoie F., Lenoir B., et al. 1996. Development of enzyme-linked immunoassays for human angiotensin I-converting enzyme suitable for largescale studies. J. Hypertens. 14, 719-727.

19. Gribouval O., Gonzales M., Neuhaus T. 2005. Mutations in genes in the renin-angiotensin system are associated with autosomal recessive renal tubular dysgenesis. Nat. Genet. 37, 964-968.

20. Kramers C., Danilov S.M., Deinum J., et al. 2001. A point mutation in the stalk of angiotensin-converting enzyme causes a dramatic increase in serum ACE, but no cardiovascular disease. Circulation. 104, 1236-1240.
21. Danilov S.M., Gordon K., Nesterovitch A.B., et al. 2011. Angiotensin I-converting enzyme mutation (Y465D) causes dramatic increase in blood ACE via accelerated ACE shedding due to changes of ACE dimerization. PLoS ONE. 6, e25952.

22. Nesterovitch A.B., Hogarth K.D., Adarichev V.A., et al. 2009. Point mutation of angiotensin I-converting enzyme (Trp1197Stop) determines a dramatic increase in blood ACE. PLoS ONE. 4, e8282.

23. Persu A., Lambert M., Deinum J., et al. 2013. A novel splice-site mutation in angiotensin I-converting enzyme (ACE) gene, c. 3691+1G $>$ A (IVS25+1G $>$ A), causes a dramatic increase in circulating ACE through deletion of the transmembrane anchor. PLOS ONE .8, e59537.

24. Soubrier F., Alhenc-Gelas F., Hubert C., et al. 1988. Two putative active centers in human angiotensin I-converting enzyme revealed by molecular cloning. Proc. Natl. Acad. Sci. U. S. A. 85, 9386-9390.

25. Chen H.-L., Lunsdorf H., Hecht H.-J., Tsai H. 2010. Porcine pulmonary angiotensin I-converting enzyme: Biochemical characterization and spatial arrangement of the $\mathrm{N}$ - and $\mathrm{C}$-domains by three-dimensional electron-microscopic reconstruction. Micron. 41, 674685.

26. Menard J., Patchett A.A. 2001. Angiotensin-converting enzyme inhibitors. Adv. Protein Chem. 56, 13-75.

27. Sakharov I.Y., Dukhanina E.A, Danilov S.M. 1986. Isolation and properties of the angiotensin-converting enzyme from human lungs. Biokhimiya. 51, 946-951.

28. Sakharov I.Y., Danilov S.M., Dukhanina E.A. 1987. Affinity chromatography and some properties of the angiotensin-converting enzyme from human heart. Biochim. Biophys. Acta. 923, 143-149.

29. Sakharov I.Y., Danilov S.M., Sukhova N. 1987. Isolation of human liver angiotensin-converting enzyme by chromatofocusing. Analyt. Biochem. 116, 14-17.

30. Danilov S.M., Jaspard E., Churakova T., et al. 1994. Structure-function analysis of angiotensin-converting enzyme using monoclonal antibodies. Selective inhibition of N-domain active center. J. Biol. Chem. 269, 26806-26814.

31. Tzartos S.J. 1988. Myastenia gravis studied by monoclonal antibodies to acetylcholine receptor. In Vivo. 2, $105-110$.

32. Danilov S.M., Allikmets E.Y., Sakharov I.Y., et al. 1987. Monoclonal antibodies to human angiotensin-converting enzyme. Biotech. Appl. Biochem. 9, 319-312.

33. Levinson S.S., Miller J.J. 2002. Towards a better understanding of heterophile (and the like) antibody interference with modern immunoassays. Clin. Chim. Acta Int. J. Clin. Chem. 325, 1-15.

34. Balyasnikova I.V., Metzger R., Franke F.E., Danilov S.M. 2003. Monoclonal antibodies to denatured human ACE (CD 143): Broad species specificity, reactivity on paraffin sections and detection of subtle conformational changes in the C-terminal domain of ACE. Tissue Antigens. 61, 49-62.

35. Balyasnikova I.V., Metzger R., Franke F.E., et al. 2008. Epitope mapping of mAbs to denatured human testicular ACE. Tissue Antigens. 72, 354-368. 
36. Naperova I.A., Balyasnikova I.V., Schwartz D.E., et al. 2008. Mapping of conformational mAb epitopes to the $\mathrm{C}$ domain of human angiotensin I-converting enzyme (ACE). J. Proteome Res. 7, 3396-3411.

37. Woodman Z.L., Schwager S.L., Redelinghuys P., et al. 2005. The $\mathrm{N}$ domain of somatic angiotensin-converting enzyme negatively regulates ectodomain shedding and catalytic activity. Biochem. J. 389, 739-744.

38. Balyasnikova I.V., Sun Z-L., Berestetskaya Y.V., et al. 2005a. Monoclonal antibodies $1 \mathrm{~B} 3$ and $5 \mathrm{C} 8$ as probes for monitoring the nativity of C-terminal end of soluble angiotensin-converting enzyme (ACE). Hybridoma. 24, 14-25.

39. Balyasnikova I.V., Skirgello O.E., Binevski P.V., et al. 2007. Monoclonal antibodies $1 \mathrm{G} 12$ and $6 \mathrm{~A} 12$ to the $\mathrm{N}$-domain of human angiotensin-converting enzyme: Fine epitope mapping and antibody-based method for revelation and quantification of $\mathrm{ACE}$ inhibitors in the human blood. J. Proteome Res. 6, 1580-1594.

40. Skirgello O.E., Balyasnikova I.V., Binevski P.V., et al. 2006. Inhibitory antibodies to human angiotensin-converting enzyme: Fine epitope mapping and mechanism of action. Biochemistry.45, 4831-4847.

41. Danilov S.M., Watermeyer J.M., Balyasnikova I.V., et al. 2007. Fine epitope mapping of monoclonal antibody $5 \mathrm{~F} 1$ reveals anticatalytic activity toward the $\mathrm{N}$ domain of human angiotensin-converting enzyme. Biochemistry. 46, 9019-9031.

42. Gordon K., Balyasnikova I.V., Nesterovitch A.B., et al. 2010. Fine epitope mapping of monoclonal antibodies $9 \mathrm{~B} 9$ and $3 \mathrm{G} 8$, to the $\mathrm{N}$ domain of human angiotensin I-converting enzyme (ACE) defines a region involved in regulating ACE dimerization and shedding. Tissue Antigens. 75, 136-150.

43. Balyasnikova I.V., Karran E.H., Albrecht R.FII., Danilov S.M. 2002. Epitope-specific antibody-induced cleavage of angiotensin-converting enzyme from the cell surface. Biochem. J. 362, 585-595.

44. Kost O.A., Balyasnikova I.V., Chemodanova E.E., et al. 2003. Epitope-dependent blocking of the angiotensin-converting enzyme dimerization by monoclonal antibodies to N-terminal domain of ACE: Possible link of ACE dimerization and shedding from the cell surface. Biochemistry. 42, 6965-6976.

45. Petrov M.N., Shilo V.Y., Tarasov A.V., et al. 2012. Conformational changes of blood ACE in chronic uremia. PLoS ONE. 7, e49290.

46. Danilov S.M., Deinum J., Balyasnikova I.V., et al. 2005. Detection of mutated angiotensin-converting enzyme (ACE), by serum/plasma analysis using a pair of monoclonal antibodies. Clin. Chem. 51, 1040-1043.

47. Danilov S.M., Kalinin S., Chen Z., et al. 2010. Gln1069Arg angiotensin I-converting enzyme mutation impairs transport to the cell surface resulting in selective denaturation of the C-domain. PLoS ONE. 5, e10438.

48. Danilov S.M., Wade M.S., Schwager S.L., et al. 2014. A novel angiotensin I-converting enzyme mutation (S333W) impairs N-domain enzymatic cleavage of the anti-fibrotic peptide, Ac-SDKP. PLoS ONE. 9, e88001.

49. Danilov S.M., Luensdorf H., Nesterovitch A.B., et al. 2016. Lysozyme and bilirubin bind to ACE and regu- lates ACE conformation and shedding. Sci. Rep. 6, 34913.

50. Danilov S.M., Balyasnikova I.B., Danilova A.S., et al. 2010. Conformational fingerprinting of the angiotensin-converting enzyme (ACE): Application in sarcoidosis. J. Proteome Res. 9, 5782-5793.

51. Balyasnikova I.V., Metzger R., Visintine D., et al. 2005. A new set of monoclonal antibodies to rat angiotensin I-converting enzyme (ACE) for the lung endothelial targeting. Pulm. Pharm. Ther. 18, 251-267.

52. Balyasnikova I.V., Metzger R., Sun Z.-L., et al. 2005. Development and characterization of rat monoclonal antibodies to denatured mouse angiotensin-converting enzyme. Tissue Antigens. 65, 240-251.

53. Balyasnikova I.V., Sun Z.-L., Metzger R., et al. 2006. Monoclonal antibodies to native mouse angiotensinconverting enzyme (CD143): ACE expression quantification, lung endothelial cell targeting and gene delivery. Tissue Antigens. 67, 10-29.

54. Nikolaeva M.A., Balyasnikova I.V., Alexinskaya M.A., et al. 2006. Testicular isoform of angiotensin I-converting enzyme (ACE, CD143) on the surface of human spermatozoa: Revelation and quantification using monoclonal antibodies. Am. J. Reprod. Immunol. 55, 54-68.

55. Franke F.E., Pauls K., Kerkman L., et al. 2000. Somatic isoform of angiotensin I-converting enzyme in the pathology of testicular germ cell tumors. Human Pathol. 31, 1466-1476.

56. Essentials in Glycobiology, 2nd ed. 2009. Eds Varki A., Cummings R.D., Esko J.D., Cold Spring Harbor, NY: Cold Spring Harbor Lab. Press.

57. Su Y., Royle L., Radcliffe C.M., et al. 2009. Detailed $\mathrm{N}$-glycan analysis of mannose receptor purified from murine spleen indicates tissue specific sialylation. Biochem. Biophys. Res. Commun. 384, 436-443.

58. Fishman A. 1963. Dynamics of the pulmonary circulation.in: Handbook of Physiology, vol. 2. Washington, DC: Am. Physiol. Soc., p. 1667.

59. Silverstein E., Friedland J., Lyons H.A., Gourin A. 1976. Elevation of angiotensin-converting enzyme in granulomatous lymph nodes and serum in sarcoidosis: Clinical and possible pathological significance. Ann. N. Y. Acad. Sci. 278, 498-513.

60. Kost O.A., Petrov M.N., Naperova I.A., et al. 2016. Conformational fingerprinting of angiotensin-converting enzyme in the blood in health and disease. Moscow Univ. Chem. Bull. 71 (1), 32-36.

61. Sidransky E. 2012. Gaucher disease: Insights from a rare Mendelian disorder. Discov. Med. 14, 273-281.

62. Kryukova O.V., Tikhomirova V.E., Golukhova E.Z., et al. 2015. Tissue specificity of human angiotensin I-converting enzyme. PLoS ONE. 10, e0143455.

63. Liddy K.A., White M.Y., Cordwell S.J. 2013. Functional decorations: Post-translational modifications and heart disease delineated by targeted proteomics. Genome Med. 5, 20.

64. Falkenhahn M., Franke F., Bohle R.M., et al. 1995. Cellular distribution of angiotensin converting enzyme after myocardial infarction. Hypertension. 25, 219-226.

65. Tikhomirova V.E., Kost O.A., Kryukova O.V., et al. 2017. ACE phenotyping in human heart. PLoS ONE. 12 (8), e0181976. doi 10.1371/journal.pone.0181976 
66. Goette A., Staack T., Rocken C., et al. 2000. Increased expression of extracellular signal-regulated kinase and angiotensin-converting enzyme in human atria during atrial fibrillation. J. Am. Coll. Cardiol. 35, 1669-1677.

67. Xiao H.D., Fuchs S., Campbell D.J., et al. 2004. Mice with cardiac-restricted angiotensin-converting enzyme (ACE) have atrial enlargement, cardiac arrhythmia, and sudden death. Am. J. Pathol. 165, 1019-1032.

68. Romer F.K. 1984. Clinical and biochemical aspects of sarcoidosis. With special reference to angiotensin-converting enzyme (ACE). Acta Med. Scand. Suppl. 690, 3-96.

69. Hohlbrugger G., Pschorr J., Dahlheim H. 1984. Angiotensin I converting enzyme in the ejaculate of fertile and infertile men. Fertil. Steril.41, 324-325.

70. Ferrara N. 2004. Vascular endothelial growth factor: Basic science and clinical progress. Endocr. Rev. 25, 581-611.

71. Grivas N., Goussia A., Stefanou D., Giannakis D. 2016. Microvascular density and immunohistochemical expression of VEGF, VEGFR-1 and VEGFR-2 in benign prostatic hyperplasia, high-grade prostate intraepithelial neoplasia and prostate cancer. Cent. Eur. J. Urol. 69, 63-71.

72. Roberts W.G., Palade G.E. 1995. Increased microvascular permeability and endothelial fenestration induced by vascular endothelial growth factor. J. Cell Sci. 108 (6), 2369-2379.

73. Hiemisch H., Gavrilyuk V., Atochina E., et al. 1993. Purification of radiolabeled monoclonal antibodies to angiotensin-converting enzyme significantly improves specificity and efficacy of its targeting into the lung. Nucl. Med. Biol. 20, 435-441.

74. Danilov S.M., Sakharov I.Y., Martynov A.V., et al. 1989. Monoclonal antibody to angiotensin-converting enzyme: A powerful tool for lung and vessel studies. J. Mol. Cell. Cardiol. 21 (Suppl. 1), 165-170.

75. Danilov S.M., Muzykantov V.R., Martynov A.V., et al. 1991. Lung is the target organ for a monoclonal antibody to angiotensin-converting enzyme. Lab. Invest. 64, 118-124.

76. Danilov S.M., Gavriljuk V.D., Franke F.E., et al. 2001. Lung uptake of antibodies to endothelial antigens: Key determinants of vascular immunotargeting. Am. J. Physiol. Lung Physiol. 280, L1335-L1347.

77. Muzykantov V.R. 2005. Biomedical aspects of targeted delivery of drugs to pulmonary endothelium. Expert Opin. Drug Deliv. 5, 909-926.

78. Chrastina A., Valadon P., Massey K.A., Schnitzer J.E. 2010. Lung vascular targeting using antibody to aminipeptidase P: CT-SPECT imaging, biodistribution and pharmacokinetic analysis. J. Vasc. Res. 47, 531-543.

79. Somia N., Verma I.M. 2000. Gene therapy: Trials and tribulations. Nat. Rev. Genet. 2, 91-99.

80. Reynolds P.N., Zinn K.R., Gavrilyuk V.D., et al. 2000. A targetable, injectable adenoviral vector for selective gene delivery to pulmonary endothelium in vivo. Mol. Ther. 2, 562-578.

81. Muzykantov V.R., Barnathan E., Atochina E., Fisher A. 1996. Targeting of conjugated plasminogen activators to the pulmonary vasculature. J. Pharm. Exp. Ther. 279, 1026-1034.

82. Muzykantov V.R., Atochina E.N., Ischiropoulos H., et al. 1996. Immunotargeting of antioxidant enzymes to the pulmonary endothelium. Proc. Natl. Acad. Sci. U. S. A. 93, 5213-5218.

83. Atochina E.N., Balyasnikova I.V., Danilov S.M., et al. 1998. Catalasetargeting to the surface endothelial antigens protects pulmonary vasculature against oxidative insult. Am. J. Physiol. Lung Physiol. 275, L806-L817.

84. Nowak K., Weih S., Metzger R., et al. 2007. Immunotargeting of catalase to lung endothelium via anti-ACE antibodies attenuates ischemia-reperfusion injury of the lung in vivo. Am. J. Physiol. Lung Physiol. 293, L162-L169.

85. Nowak K., Hanusch C., Nicksch K., et al. 2010. Preischemic conditioning of the pulmonary endothelium by immunotargeting of catalase via angiotensin-converting enzyme antibodies. Eur. J. Cardiothorac. Surg. 37, 859-863.

86. Reynolds P.N., Nicklin S.A., Kaliberova L., et al. 2001. Combined transductional and transcriptional targeting improves the specificity of transgene expression in vivo. Nat. Biotechnol. 19, 838-842.

87. Miller W.H., Brosnan M.J., Graham D., et al. 2005. Targeting endothelial cells with adenovirus expressing nitric oxide synthase prevent elevation of blood pressure in stroke prone spontaneously hypertensive rats. Mol. Ther. 12, 321-327.

88. Reynolds A.M., Xia M., Holmes M.D., et al. 2007. Bone morphogenetic protein type 2 receptor (BMPR2) gene therapy attenuates hypoxic pulmonary hypertension. Am. J. Physiol. Lung Physiol. 292, L1182-L1192.

89. Reynolds A.M., Holmes M.D., Danilov S.M., Reynolds P.N. et al. 2012. Targeted delivery of bone morpho-genetic protein receptor type- 2 attenuates pulmonary hypertension in rats. Eur. Resp. J. 39, 329-343.

90. Morecroft I., White K., Caruso P., et al. 2012. Gene therapy by targeted adenovirus-mediated knockdown of pulmonary endothelial Tph1 attenuates hypoxiainduced pulmonary hypertension. Mol. Ther. 20, 15161528.

91. United Network for Organ Sharing Scientific Registry Data. www.unos.org.

92. Chiu M.L., Gilliland G.L. 2016. Engineering antibody therapeutics. Curr. Opin. Struct. Biol. 38, 163-173.

93. Balyasnikova I.V., Berestetskaya Y.V., Visintine D.J., et al. 2010. Cloning and characterization of a singlechain fragment of monoclonal antibody 9B9 for targeting angiotensin-converting enzyme. Microvasc. Res. 80, 355-364.

94. Bruggemann M., Osborn M.J., Ma B., et al. 2015. Human antibody production in transgenic animals. Arch. Immunol. Ther. Exp. (Warszawa). 63, 101-108.

95. Paduch M., Koide A., Uysal S., et al. 2013. Generating conformation-specific synthetic antibodies to trap proteins in selected functional states. Methods. 60, 3-14.

96. Yakimenko E.F., Yazova A.K., Goussev A.I., Abelev G.I. 2003. New approaches for the detection and characterization of alpha-fetoprotein epitope variants. Tumour Biol. 24, 1-8. 